\title{
Mechanisms of Allergen-Specific Sublingual Immunotherapy and the Use of Biological Markers in Allergic Rhinitis
}

Mohamed H. Shamji, PhD ${ }^{1,2,3, *}$

\author{
Address \\ ${ }^{1}$ Immunomodulation and Tolerance Group, Allergy and Clinical Immunology, \\ Imperial College London, London, SW7 2AZ, UK \\ ${ }^{2}$ Allergy and Clinical Immunology, National Heart and Lung Institute, \\ Imperial College London, London, SW7 2AZ, UK \\ ${ }^{3}$ MRC \& Asthma UK Centre in Allergic Mechanisms of Asthma, London, UK \\ *Immunomodulation and Tolerance Group, Department of Allergy \& Clinical \\ Immunology, National Heart and Lung Institute, Faculty of Medicine, Imperial \\ College London, London, SW7 2AZ, UK \\ Email: m.shamji@imperial.ac.uk
}

Published online: 9 January 2014

(C) Springer International Publishing AG 2014

Keywords Allergen immunotherapy - Sublingual immunotherapy - Immunoglobulin $\mathrm{G}_{4}$. Biomarkers · Vaccine

\section{Opinion statement}

Clinical and immunologic tolerance are hallmarks of successful allergen sublingual immunotherapy (SLIT) in carefully selected patients. Clinical benefit such as reduced symptoms, pharmacotherapy intake, and improvement of quality of life persists following discontinuation of treatment. Successful SLIT is associated with suppression of allergic inflammatory cells such as mast cells, eosinophils, and basophils. Furthermore, SLIT immunomodulates allergen-specific Th2 responses in the tissue (target organ) and the periphery. The immunologic tolerant state induced following SLIT is associated with induction of allergen-specific IL-10+, TGF- $\beta+$, and FoxP3+ regulatory memory $\mathrm{T}$ cells. $\mathrm{B}$ cell responses, in particular $\mathrm{IgG}_{4}$-associated blocking antibodies and IL-10+ regulatory B cells, are also induced following allergen immunotherapy (AIT). These events are followed by suppression of allergen-specific proliferation Th2 responses and result in immune deviation from a $T$ 
helper 2-type to T helper 1-type response. Despite insight gained with regard to the mechanisms of SLIT, to date there are no validated biomarkers that are predictive of the clinical response to treatment. This review reports recent advances in understanding mechanisms of SLIT and outlines relevant potential biomarkers for monitoring allergen-specific immunotherapy.

\section{Introduction}

Allergic rhinitis (AR) is a type-I hypersensitivity (allergic) disease resulting in biphasic clinical response. It is characterised by chronic inflammation of the lining of the nasal mucosa resulting from early-and late-phase responses upon exposure to prevailing common aeroallergens such as tree, grass, or weed pollens in the spring and summer months $[1,2]$. Typical symptoms include sneezing, rhinorrhoea, nasal congestion, and nasal itching. AR is often associated with ocular (eye) symptoms of allergic conjunctivitis [3]. Recent classification of allergic rhinitis has taken into consideration the impact of symptoms on quality of life. The severity of symptoms is divided into mild or moderate/severe [4, 5]. A substantial increase in the prevalence of seasonal allergic rhinitis has been reported in industrialised countries, particularly in Western Europe and the United States, where it affects onequarter of the population [6-8]. Moreover, it is a risk factor for developing allergic asthma in adults, with up to $30 \%$ of patients reporting asthma symptoms [9-11]. AR impacts on a patient's social life. It affects learning performance in school children [12] and work productivity in adults [13]. It has a major impact on quality of life and is a proven substantial socioeconomic burden [14].

The current management of allergic rhinitis consists of patient education, avoidance of allergen, pharmacotherapy, and allergen immunotherapy [15]. Antihistamines can be used for both intermittent and persistent disease, reducing symptoms such as nasal itchiness, sneezing, and rhinorrhea, and they have been shown to improve work and school performance in pollen-induced rhinitis [16]. Oral and topical decongestants have been shown to relieve nasal congestion effectively in the short term but are not effective for other symptoms such as sneezing and rhinorrhoea, and their long-term use is to be avoided due to the risk of developing rebound congestion and rhinitis medicamentosa. Chromones, which stabilise mast cells, are recommended for topical intraocular treatment. In placebo-controlled studies the leukotriene receptor antagonist montelukast has been shown to reduce symptoms of nasal congestion as well as rhinorrhea and sneezing in allergic rhinitis. However, the effects of leukotriene antagonists are modest, only effective in $5 \%$ of patients compared to placebo [17]. In contrast, intranasal corticosteroids show much greater efficacy in the treatment of seasonal allergic rhinitis when compared to antihistamines [18] and leukotriene antagonists [19]. Treatment with antiimmunoglobulin E antibody has demonstrated efficacy in seasonal allergic rhinitis. This therapy consists of a recombinant humanised monoclonal anti-IgE antibody (omalizumab) which binds to the constant region $(\mathrm{Fc})$ of the IgE molecule, thereby preventing binding of IgE to the high-affinity $\operatorname{IgE}$ receptor on mast cells and basophils, whilst avoiding the risk of IgE cross-linking leading to anaphylaxis. It has also been shown to reduce IgE levels in serum [20].

Allergen immunotherapy (AIT) is highly effective for select individuals with IgE-mediated diseases, such as allergic rhinitis, conjunctivitis, and venom hypersensitivity $[21 \bullet \bullet, 22,23 \bullet \bullet]$. AIT was initially reported by Leonard Noon in the early 20th century when he described his initial observations on the effects of grass pollen-specific injection immunotherapy resulting in suppression of ocular symptoms caused by the sensitising grass pollen allergen. AIT is traditionally administered subcutaneously (SCIT) [24] and has proven clinical benefit in adults and children who are sensitised and allergic to aeroallergens such as pollens (grasses and trees), house dust mite (HDM), animal dander, and pollen-induced allergic rhinitis with/with- 
out asthma [24]. In recent years, sublingual immunotherapy (SLIT) has emerged as an alternative to SCIT and has been shown to be effective with a superior safety profile compared to SCIT.

\section{Sublingual immunotherapy}

\section{Clinical efficacy}

Sublingual immunotherapy (SLIT) has recently emerged as an effective and safe alternative route to deliver immunotherapy. Clinical efficacy of sublingual immunotherapy has been reported in Cochrane systematic reviews and meta-analyses [25•]. Optimal high doses of grass pollen tablet treatment have been established in two separate randomised double-blind placebocontrolled studies $[26,27]$. A four- to six-month pre-seasonal followed by continued seasonal treatment with SLIT tablets resulted in increased clinical efficacy when compared to two months' pre-seasonal treatment. A recent five-year double-blind placebo-controlled study of SLIT investigated prolonged efficacy and induction of tolerance. The study consisted of three years of treatment with SQ-standardised grass SLIT tablet or placebo and two years of blinded follow-up after discontinuation of treatment. Clinical endpoints were measured, including rhinoconjunctivitis symptom and medication scores, combined scores, asthma symptom and medication scores, quality of life, days with severe symptoms, as well as immunologic endpoints and safety parameters. The mean rhinoconjunctivitis daily symptom score was significantly reduced (25-36 \%) in the SLIT-treated group when compared to the placebo group over five consecutive grass pollen seasons. The rhinoconjunctivitis daily medication score was reduced by $20 \%$ to $45 \%$ for seasons one through four. In all three seasons during treatment and two seasons during withdrawal of treatment, the percentage of days with severe symptoms during the peak grass pollen exposure was decreased from $49 \%$ to $63 \%$ in the SLIT-treated group when compared to placebo-treated group. A recent double-blind placebo-controlled study of three years' treatment with grass allergen tablets followed by two years follow-up showed that the active treatment group exhibited a sustained and persistent clinical improvement for two years after discontinuation of treatment [28, 29••].

Langerhans cells that reside in the oral mucosa constitutively express FceRI, major histocompatibility complex (MHC) class I, II, and co-stimulatory and co-inhibitory molecules [30]. These cells are highly efficient in antigen presentation to T cells. Cross-linking of FceRI on monocytes induces production of IL-10 [31] and indoleamine 2,3-dioxygenase [32].Indoleamine 2,3dioxygenase is associated with reduced tryptophan levels and consequently impaired T-cell stimulatory capacity. Allam and colleagues recently demonstrated that ligation of Toll-like receptor 4 (TLR4) on isolated oral Langerhans cells resulted in increased production of IL-10 [33]. Subsequent co-culture experiments revealed a decreased T-cell proliferative response and a parallel induction of $\mathrm{T}$ cells with a regulatory phenotype. 
Clinical studies of SLIT are heterogeneous, and a wide range of laboratory techniques have been used to measure putative immunological mechanisms, which may at least partly explain the variability of results. Tracer studies of radioiodine-labeled allergen have shown that allergen is retained within the mouth for at least 2 hours and up to 18-20 hours following sublingual administration, affording opportunities for both local as well as systemic effects on the immune system [34]. Few studies have considered assessing the immune cell infiltration of the oral mucosa tissue before and after SLIT in humans. A study reported equal numbers of local CD1a+ dendritic cells (DCs) and CD3+ T cells before and after SLIT [35]. The cellular distribution of various immune cells during SLIT has been studied recently in more detail. Epithelial FoxP3 + regulatory T cells were elevated in SLIT patients when compared with the placebo group and were associated with reduced subepithelial CD1c+ myeloid DCs (mDCs) and mast cells [36]. The effects of SLIT on allergic effector cells have been demonstrated in patients treated with parietaria-specific SLIT. A significant reduction in the number of eosinophils, neutrophils, and ICAM-1 expression in the nasal mucosa was reported [37]. A reduction of eosinophil cationic protein $[38,39]$ and number of eosinophils has been observed in several but not all studies [40].

Studies of peripheral $\mathrm{T}$ cell responses to inhalant allergens before and after SLIT have been highly variable. Decreased T cell proliferative responses in birch [41] and grass pollen-treated patients [42] have been observed in some but not all studies $[43,44]$. Similarly, results for $\mathrm{T}$ cell cytokine production at both messenger RNA (mRNA) and protein levels have been highly variable, with some studies showing an increase in interferon gamma and/or decrease in Th2 cytokines [45-47] and others showing no changes [43, 48, 49]. A more consistent finding (as found in SCIT) has been increases in IL-10 production in peripheral T cells, which have been observed at protein [41, $48,49]$ and mRNA levels [47] in several but not all studies [43].

A well-designed mechanistic study by Bohle and colleagues on small numbers of birch-treated patients revealed a reduction in $\mathrm{T}$ cell proliferative responses to Bet v1 that was accompanied by increases in IL-10 [41]. This suppression was reversed by using neutralising anti-IL-10 antibody or depletion of $\mathrm{CD} 25^{+}$cells from the cultures, which implied involvement of regulatory T cells (Treg). In another study of HDM-SLIT, allergen-induced CD4+ T cell proliferation and IL-5 production were significantly decreased after active treatment in contrast to no change in the placebo-treated group [50]. The allergen-induced T cell proliferative responses were sTGF- $\beta$ RII-dependent at six months. In this study, Foxp3+ Tregs were increased in the HDM-SLIT-treated but not placebo-treated group. Another study of grass pollen-SLIT also showed increased in Foxp3+ T regulatory cells in the nasal mucosa [36]. A recent study investigated the epigenetic modification of memory Treg cells during dual HDM and grass pollen SLIT. Methylated CpG sites within the Foxp3 locus of enriched memory CD45RO+Treg cells were enumerated before and 12 months following immunotherapy. DNA methylation was decreased in CD45RO+Treg cells at the FOXP3 locus in subjects after 12 months treatment with dual AIT, whereas no changes in FOXP3 
locus DNA methylation were observed in CD45RO+ Treg cells in either placebo-treated allergic participants or healthy normal controls [51]. These observations support the theory that functional FoxP3+ Tregs are induced during SLIT.

\section{Dendritic cell responses during SLIT}

In vivo murine and in vitro human studies have shown that proinflammatory epithelial-derived mediators and cytokines, such as TSLP, IL-25, IL-33, prime DCs to polarise naïve T cell responses towards a pro-allergic Th2 phenotype $[52,53]$. AIT may dampen these inflammatory epithelial responses, resulting in induction of tolerogenic DCs, which are able to polarise T cells towards an IL-10-producing Treg phenotype. The inducible IL-10+ Tregs, in turn, may suppress pro-inflammatory DCs and modulate Th2 responses [54,55].

AIT has been shown to augment peripheral DC TLR9-mediated innate immune function [56]. A three- to fivefold increase in IFN- $\alpha$ production by plasmacytoid dendritic cells (pDCs) in response to in vitro CpG stimulation was demonstrated in subjects who received HDM-specific AIT. A recent study revealed that different subsets of human DCs enriched from peripheral blood could preferentially induce IL-10+ regulatory $\mathrm{T}$ cells and subsequently sup-

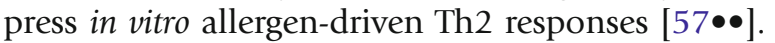

A novel inhibitory cytokine, Interleukin-27 (IL-27), which is produced by dendritic cells following in vitro TLR4 stimulation by LPS, has been shown to suppress $\mathrm{T}$ helper 2 responses in patients with seasonal allergic rhinitis

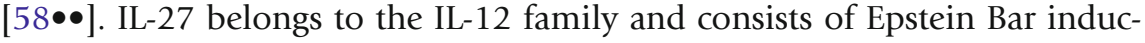
ible gene 3 (EBI-3) [59] and IL-12p28 [60]. In vitro IL-27 was found to suppress grass pollen allergen-induced PBMC proliferation in a dose-dependent manner. IL-27 upregulated mRNA T-bet and c-Maf expression and downregulated GATA-3. Additionally, IL-27 downregulated IL-4 and IL-5 and upregulated IL-10 and IFN-g mRNA expression. Moreover, T effector cell proliferation was suppressed when grass pollen-stimulated IL-27-primed DCs were cultured with T effector cells. The immunomodulatory effects of IL27 during AIT remain to be further determined and validated in other SLIT studies.

\section{Immunoglobulin responses during SLIT}

During pollen SLIT, increases in allergen-specific IgE occur within weeks and do not appear to be associated with adverse reactions. These early increases are followed by blunting of seasonal rises in IgE. There follows an increase in allergen-specific IgG and $\operatorname{IgG}_{4}$. These elevations are both time- and allergen dose-dependent [27] and are progressive for at least two years [61] although of lower magnitude than observed during SCIT [62]. These protective $\operatorname{IgG}_{4}$

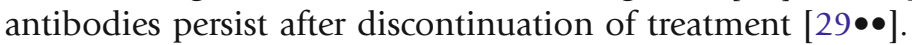

Some studies have shown increases in specific $\mathrm{IgG}_{4}$ in the absence of demonstrable efficacy [63], whereas others have shown no difference in IgG levels, likely related to the lower allergen doses employed [43], particularly in relation to HDM SLIT [40, 44, 64]. These findings raise the issue of causality versus bystander effects. In functional assays, sera obtained after grass pollen SLIT was able to inhibit IgE-binding in-vitro [36, 61]. The heterogeneity of 
immunological responses in particular in relation to allergen-specific IgE and $\mathrm{IgG}_{4}$ antibodies may be largely explained on the basis of the allergen dose, duration of treatment, and types of allergens used.

\section{Potential surrogate/predictive biomarker of SLIT}

In order to evaluate potential biomarkers of effective SLIT to predict responders from non-responders or to inform whether to discontinue or recommence treatment, various attempts have been undertaken to assess the relationship between $\mathrm{T}$ and $\mathrm{B}$ cell responses in the periphery and/or target organs. Hitherto, only serum-based biomarkers have been employed in large clinical trials, as current assays assessing cellular $\mathrm{T}$ and $\mathrm{B}$ cell responses are complex and challenging to standardise between laboratories for multicentre studies or for monitoring individual subjects.

\section{Immunoreactive immunoglobulin G}

Elevation in allergen-specific $\operatorname{IgG}_{1}$ and $\operatorname{IgG}_{4}$ levels has been observed in both serum and local target organs following SLIT $[28,29 \bullet \bullet, 65 \bullet \bullet]$ and SCIT $[23 \bullet \bullet, 66,67]$. Despite an increase in $\operatorname{IgG}_{4}$ antibody levels, however, these studies failed to establish a relationship between $\operatorname{IgG}_{4}$ antibodies and clinical efficacy. Thus, quantitative allergen-specific $\operatorname{IgG}_{4}$ may serve only as a marker of allergen exposure and not clinical outcome. Moreover, it has also been reported that $\operatorname{IgG}_{4}$ antibodies induced following SLIT may inhibit basophil activation and prevent CD23-mediated IgE-facilitated allergen presentation by competing with allergen-specific IgE in B cells to T cell clones [68, 69].

Inhibition of IgE-facilitated allergen presentation

In the mid-1930s, Cooke and colleagues were the first to report the induction of serum inhibitory antibody activity following AIT [70].Subsequent studies further characterised these antibodies, which were found to be retained within the IgA and IgG fraction in serum [71, 72]. Later, using serum obtained from subjects that had undergone birch pollen AIT, Van Neerven and colleagues demonstrated that the inhibitory activity for IgE-facilitated antigen presentation by $\mathrm{B}$ cells to $\mathrm{T}$ cell clones could translate into a reduction in allergen-driven $\mathrm{T}$ cell proliferation and cytokine production [68]. These findings were subsequently reproduced in subjects who had undergone grass pollen AIT [69] using a simplified flow cytometry-based assay in which the cooperative binding of allergen-IgE complexes binding to low-affinity IgE receptor FceRII (CD23) on the surface of B cells was detected (IgE-FAB). The binding of allergen-IgE complexes to B cells [69] was shown to correlate with the vigour of $\mathrm{T}$ cell clone proliferation. The IgE-FAB is an in vitro biofunctional cellular assay that is highly reproducible, with within-assay and between-assay reproducibility of $4 \%$ and $12 \%$, respectively, that can be utilised to detect IgG-associated serum inhibitory activity during AIT. Furthermore, grass pollen-specific $\mathrm{IgG}_{4}$ antibodies with inhibitory activity for IgE-FAB are found to be elevated in subjects treated with SCIT. Interestingly, this inhibitory activity for IgE-facilitated allergen binding was demonstrated in post-immunotherapy serum and co-purified with $\operatorname{IgG}_{4}$-containing fractions $[23 \bullet \bullet, 73 \bullet \bullet, 74,75 \bullet \bullet$ ]. In a randomised double-blind placebo-controlled study of SLIT that included 238 moderate to severe grass pollen- 
allergics with or without asthma, clinical efficacy following SLIT grass treatment was associated with sustained increases in serum grass pollen-specific $\mathrm{IgG}_{4}$ antibodies. This finding was associated with parallel increases in serum IgE-blocking factor and serum inhibitory activity for the binding of allergenIgE complexes to B cells. Notably, the immunologic changes persisted two years after the completion of treatment, consistent with long-term clinical benefit $[29 \bullet \bullet]$.

At this time, it is necessary to further validate whether IgE-FAB inhibitory activity could be used as a surrogate and/or predictive marker of clinical efficacy within individual patients. The primary deficiency in previous studies has been the lack of data from a baseline pollen season in order to be able to define individuals as 'responders' or 'non-responders'. Nonetheless, a modest inverse correlation has been demonstrated between combined symptom and rescue medication scores and

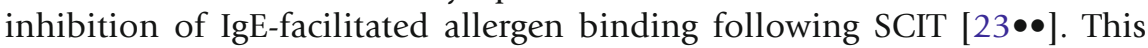
association needs to be tested following SLIT.

The extent to which IgE is hindered from binding to allergens and thus

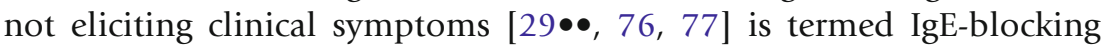
factor. A functional solid-phase assay has been developed and can be utilised to examine this aspect. In North American subjects with seasonal allergic rhinitis, increases in Phl p5-specific $\mathrm{IgG}_{4}$ and IgE-blocking factor have been demonstrated in the actively-treated group when compared to those who received placebo tablets following grass pollen SLIT treatment

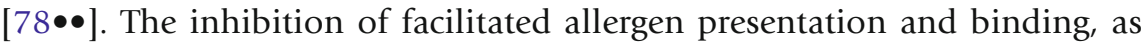
well as basophil histamine release, has now also been linked to IgEblocking factor by Würtzen and colleagues, wherein they observed a significant reduction of IgE-FAB, IgE-blocking factor, and basophil histamine release after one year of treatment and noted that this effect was sustained during the second year of treatment [76]. This established a clear correlation between CD23-mediated IgE-facilitated allergen binding as a measure of $\mathrm{T}$ cell activation and serum IgE-blocking factor and basophil histamine release. IgE-FAB, therefore, represents a more physiologic readout of functional $\operatorname{IgG}_{1}$ and $\mathrm{IgG}_{4}$ antibodies correlating with

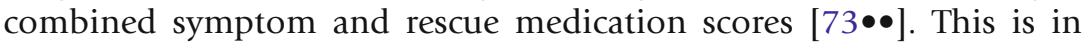
contrast to IgE-blocking factor, which accounts for all serum blocking antibodies that compete with IgE for the allergen on a solid-phase matrix in vitro.

Similar to $\mathrm{IgG}_{4}$, immunoglobulin $\mathrm{A}$ is also a noninflammatory isotype that is unable to activate, complement, or partake in immune complex formation [79]. An elevation in allergen-specific IgA $\mathrm{A}_{2}$ antibodies and polymeric $\operatorname{Ig} \mathrm{A}_{2}$ levels has been reported following grass pollen-specific SCIT. Moreover, it has also been reported that passive sensitisation of monocytes using purified polymeric Ig $\mathrm{A}_{2}$ from IgA-containing serum obtained post immunotherapy, followed by in vitro cross-linking of IgA on monocytes by antigen or anti-IgA, can result in IL-10 production [80]. Hence, the secretion of IL-10 from ac- 
cessory cells may sequentially favour immunoglobulin isotype classswitching in favour of $\operatorname{IgG}_{4}$ antibody production. Allergen-specific $\operatorname{IgA}_{2}$ has been shown to increase following grass pollen SLIT, and these findings further highlight the role for IgA antibodies in the induction of tolerance. Their use as a predictive biomarker, however, warrants further investigations.

\section{Ratio of specific IgE/Total IgE}

A recent clinical study evaluated the ratio of serum-specific IgE/total IgE in timothy grass pollen immunotherapy as a potential predictive marker for clinical efficacy [81], which involved in vitro analysis of patients who had received four years of conventional or sublingual immunotherapy. Serum total IgE (t-IgE) and specific IgE (s-IgE) levels, blood eosinophil counts, and serum s-IgE/t-IgE ratios were examined and assessed for correlation with clinical response as measured by visual analogue scores (VAS). Receiver operating characteristic (ROC) analysis for each in vitro biomarker showed a greater diagnostic and predictive value in favour of baseline serum s-IgE/t-IgE ratios. A diagnostic/predictive cutoff value of $16.2 \%$ to predict successful SCIT outcome was established in both treatment regimes, and revealed clinical sensitivity and clinical specificity of $97.2 \%$ and $88.1 \%$, respectively [81]. However, these results could not be replicated in a randomised controlled open-label three-parallel-group study of house dust mite in monosensitised asthmatic/rhinitis children to HDM who received SLIT, SCIT, or pharmacotherapy. The results from this study displayed no significant

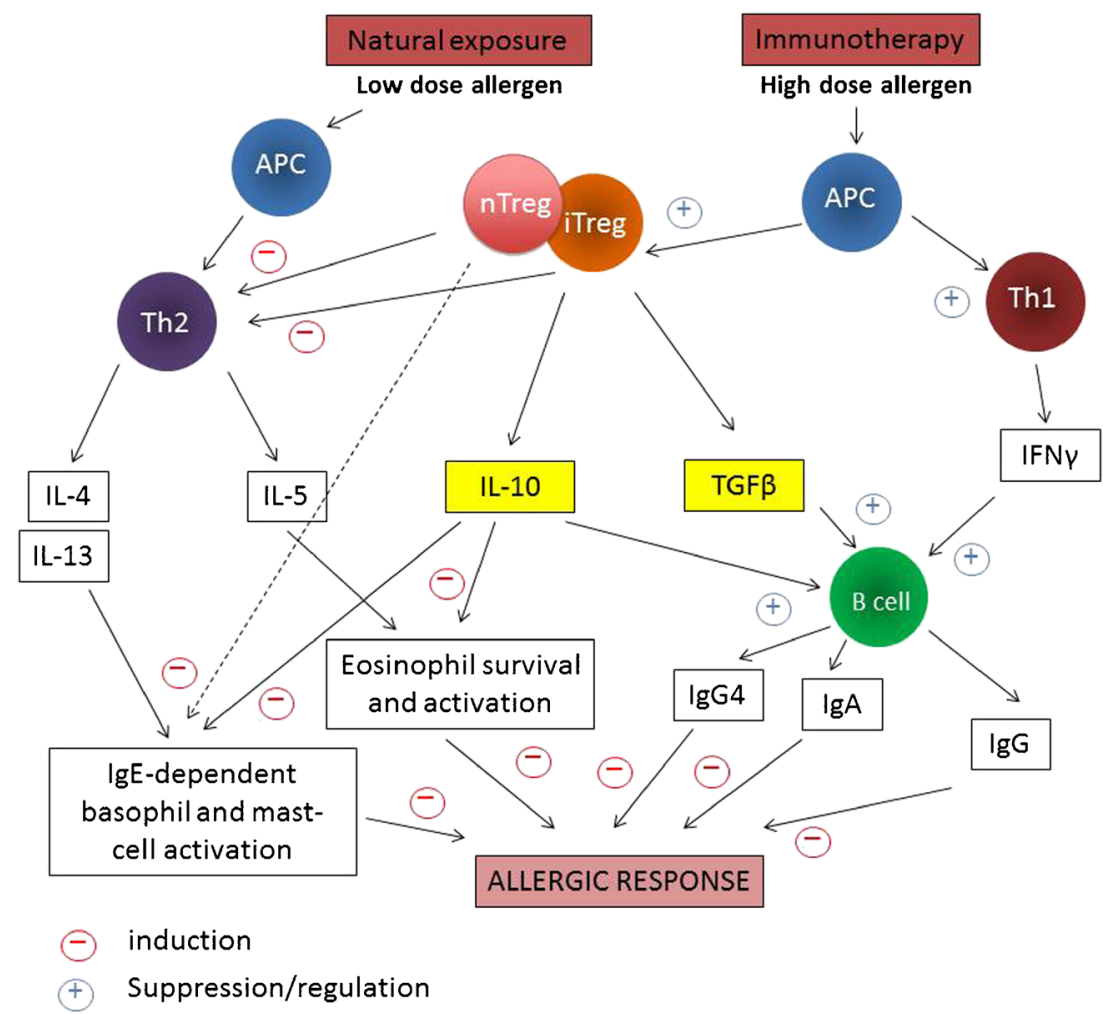

Figure 1. Immunological mechanisms of sublingual immunotherapy. Low-dose allergen exposure at mucosal surfaces in atopic individuals results in type I IgEmediated allergic responses. High-allergen dose through sublingual oral route readdresses the balance between $\mathrm{TH} 2$ / $\mathrm{TH} 1$ responses in favour of $\mathrm{TH} 1$ responses. This is accompanied by an increase in the ratio of IFN-g (Th1 cytokines) to IL-4, IL-5 and IL-13 (Th2 cytokines). The induction of inducible Treg cells (iTreg) and natural Treg cells (nTreg) and associated cytokines such as IL-10 and TGF-b following SLIT play an important role in suppressing pro-inflammatory Th2 responses and contributes towards the induction of allergen-specific IgA1, $\mathrm{IgA} 2$ and in particular IgG4 antibodies with inhibitory activity. IgG4 antibodies are able to suppress FceRI-and CD23-mediated IgEfacilitated allergen presentation and basophil histamine release. 
correlation between combined symptoms and medication scores or VAS and the ratio of serum s-IgE/t-IgE, which could be attributed to the small sample size in each treated group. Therefore, further assessment of serum s-IgE/t-IgE ratios in large randomised double-blind placebo-controlled studies are necessary to further evaluate the utility of s-IgE/t-IgE as a biomarker for effective immunotherapy. Use of recombinant allergens for accurate in vitro analysis of both individual major and minor allergens and the targeted use of a known recombinant or mixture of recombinant allergens for therapy will likely provide further clarification [82].

\section{STAB1 and C1Q RNA expression}

Proteomic analysis and mass spectroscopy of peripheral human DCs identified two potential candidate proteins, namely stabilin-1 (STAB1) and the complement component $\mathrm{C} 1 \mathrm{Q}$ as potentially representing a tolerogenic signature of DCs. Ex vivo studies involving quantitative polymerase chain reaction of peripheral blood mononuclear cells purified from blood drawn before/after grass pollen SLIT revealed elevations in STAB1 and C1Q RNA expression that corre-

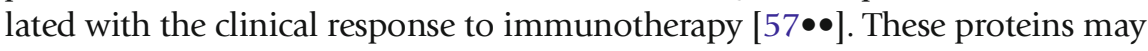
be relevant for inducing tolerogenic $\mathrm{T}$ regulatory responses.

\section{Conclusions}

Allergen immunotherapy is effective and induces long-lasting immunological and clinical tolerance that persists for years following cessation of treatment. Immunotherapy is associated with suppression of allergic inflammation in target organs and increased $\mathrm{IgG}_{4-}$ and $\mathrm{IgA}_{2}$-associated blocking antibodies. The induction of blocking antibodies is accompanied by suppression of undesired allergen-specific Th2 cell responses (Fig. 1). This suppression occurs within weeks or months as a result of the induction of regulatory $\mathrm{T}$ cells that exert their effects by mechanisms involving cell-cell contact and also by release of immunomodulatory cytokines such as IL-10 and TGF- $\beta$. The more delayed appearance of antigen-specific Th1 responses and alternative mechanisms such as Th2cell anergy and/or apoptosis may also be involved. A greater understanding of these mechanisms has provided potential surrogate clinical/ immunological efficacy biomarkers and has led to novel immunotherapy strategies, although the mechanisms of long-term clinical tolerance remain to be further fully elucidated.

\section{Compliance with Ethics Guidelines}

\section{Conflict of Interest}

Mohamed Shamji declares that he has no conflict of interest.

\section{Human and Animal Rights and Informed Consent}

This article does not contain any studies with human or animal subjects performed by any of the authors. 


\section{References and Recommended Reading}

Papers of particular interest, published recently, have been highlighted as:

- Of importance

•• Of major importance

1. Bousquet J, Demoly P, Michel FB. Specific immunotherapy in rhinitis and asthma. Ann Allergy Asthma Immunol. 2001;87 Suppl 1:38-42.

2. Bauchau V, Durham SR. Prevalence and rate of diagnosis of allergic rhinitis in Europe. Eur Respir J. 2004;24(5):758-64.

3. Kay AB. Allergy and allergic diseases. Second of two parts. N Engl J Med. 2001;344:109-13.

4. Bachert C. Allergic rhinitis and its impact on asthma (ARIA)-what does it mean for the future of SIT? Arb Paul Ehrlich Inst Bundesamt Sera Impfstoffe Frankf A M. 2003; 229-235.

5. Bousquet J, Khaltaev N, Cruz AA, Denburg J, Fokkens WJ, Togias A, et al. Allergic rhinitis and its impact on asthma (ARIA) 2008 update (in collaboration with the World Health Organization, GA(2)LEN and AllerGen). Allergy. 2008;63 Suppl 86:8-160.

6. Bauchau V, Durham SR. Prevalence and rate of diagnosis of allergic rhinitis in Europe. Eur Respir J. 2004;24:758-64.

7. Bauchau V, Durham SR. Epidemiological characterization of the intermittent and persistent types of allergic rhinitis. Allergy. 2005;60:350-3.

8. Phipatanakul W. Allergic rhinoconjunctivitis: epidemiology. Immunol Allergy Clin North Am. 2005;25:263-81. vi.

9. Guerra S, Sherrill DL, Martinez FD, Barbee RA. Rhinitis as an independent risk factor for adult-onset asthma. J Allergy Clin Immunol. 2002;109:419-25.

10. Demoly P, Bozonnat MC, Dacosta P, Daures JP. The diagnosis of asthma using a self-questionnaire in those suffering from allergic rhinitis: a pharmacoepidemiological survey in everyday practice in France. Allergy. 2006;61:699-704.

11. Demoly P, Gauchoux R, Morera P, Touron D, Daures JP. The place of spirometry in the diagnosis of asthma in those suffering from allergic rhinitis: a pilot study. Allergy. 2005;60:1089-90.

12. Simons FE. Learning impairment and allergic rhinitis. Allergy Asthma Proc. 1996;17:185-9.

13. Cockburn IM, Bailit HL, Berndt ER, Finkelstein SN. Loss of work productivity due to illness and medical treatment. J Occup Environ Med. 1999;41:948-53.

14. Malone DC, Lawson KA, Smith DH, Arrighi HM, Battista C. A cost of illness study of allergic rhinitis in the United States. J Allergy Clin Immunol. 1997;99:22-7.

15. Bousquet J, van Cauwenberge P, Aït Khaled N, Bachert C, Baena-Cagnani CE, Bouchard J, et al.
GA2LEN Pharmacologic and anti-IgE treatment of allergic rhinitis ARIA update (in collaboration with GA2LEN). Allergy. 2006;61:1086-96.

16. Murray JJ, Nathan RA, Bronsky EA, Olufade AO, Chapman D, Kramer B. Comprehensive evaluation of cetirizine in the management of seasonal allergic rhinitis: impact on symptoms, quality of life, productivity, and activity impairment. Allergy Asthma Proc. 2002;23:391-8.

17. Wilson AM, O'Byrne PM, Parameswaran K. Leukotriene receptor antagonists for allergic rhinitis: a systematic review and meta-analysis. Am J Med. 2004;116:338-44.

18. Weiner JM, Abramson MJ, Puy RM. Intranasal corticosteroids versus oral H1 receptor antagonists in allergic rhinitis: systematic review of randomised controlled trials. BMJ. 1998;317:1624-9.

19. Nathan RA. Leukotriene receptor antagonists are not as effective as intranasal corticosteroids for managing nighttime symptoms of allergic rhinitis. J Allergy Clin Immunol. 2005;116:463-4.

20. Casale TB, Condemi J, LaForce C, Nayak A, Rowe M, Watrous $\mathrm{M}$, et al. Omalizumab seasonal allergic rhinitis trial group. Effect of omalizumab on symptoms of seasonal allergic rhinitis: a randomized controlled trial. JAMA. 2001;286:2956-67.

21.• Durham SR, Walker SM, Varga EM, Jacobson MR, O'Brien F, Noble W, et al. Long-term clinical efficacy of grass-pollen immunotherapy. N Engl J Med. 1999;341:468-75.

First study to demonstrate long term clinical effects of AIT.

22. Bousquet J, Lockey R, Malling HJ. Allergen immunotherapy: therapeutic vaccines for allergic diseases. A WHO position paper. J Allergy Clin Immunol. 1998;102:558-62.

23.• Shamji MH, Ljørring C, Francis JN, Calderon MA, Larché M, Kimber I, et al. Functional rather than immunoreactive levels of IgG4 correlate closely with clinical response to grass pollen immunotherapy. Allergy. 2012;67(2):217-26.

First study to validate a relationship between blocking antibodies and clinical response.

24. Noon L. Prophylactic inoculation against hay fever. Lancet. 1911;i:1572-3.

25. Radulovic S, Wilson D, Calderon M, Durham S. Systematic reviews of sublingual immunotherapy (SLIT). Allergy. 2011;66(6):740-52.

First systematic review of sublingual immunotherapy.

26. Durham SR, Riis B. Grass allergen tablet immunotherapy relieves individual seasonal eye and nasal 
symptoms, including nasal blockage. Allergy. 2007;62:954-7.

27. Didier A, Malling HJ, Worm M, Horak F, Jager S, Montagut A, et al. Optimal dose, efficacy, and safety of once-daily sublingual immunotherapy with a 5grass pollen tablet for seasonal allergic rhinitis. J Allergy Clin Immunol. 2007;120:1338-45.

28. Durham SR, Emminger W, Kapp A, Colombo G, de Monchy JGR, Rak S, et al. Long-term clinical efficacy in grass pollen-induced rhinoconjunctivitis after treatment with SQ-standardized grass allergy immunotherapy tablet. J Allergy Clin Immunol. 2010;125(1):131-8. e1-7.

29.• Durham SR, Emminger W, Kapp A, de Monchy JGR, Rak S, Scadding GK, et al. SQ-standardized sublingual grass immunotherapy: confirmation of disease modification 2 years after 3 years of treatment in a randomized trial. J Allergy Clin Immunol. 2012;129(3):717-725.e5.

First study to demonstrate long term clinical effects of SLIT.

30. Allam JP, Novak N, Fuchs C, Asen S, Berge S, Appel T, et al. Characterization of dendritic cells from human oral mucosa: a new Langerhans' cell type with high constitutive FcepsilonRI expression. J Allergy Clin Immunol. 2003;112:141-8.

31. Novak N, Bieber T, Katoh N. Engagement of Fc epsilon RI on human monocytes induces the production of IL-10 and prevents their differentiation in dendritic cells. J Immunol. 2001;167:797-804.

32. von Bubnoff D, Matz H, Frahnert C, Rao ML, Hanau $\mathrm{D}$, de la Salle $\mathrm{H}$, et al. FcepsilonRI induces the tryptophan degradation pathway involved in regulating $\mathrm{T}$ cell responses. J Immunol. 2002;169:1810-6.

33. Allam JP, Peng WM, Appel T, Wenghoefer M, Niederhagen $\mathrm{B}$, Bieber T, et al. Toll-like receptor 4 ligation enforces tolerogenic properties of oral mucosal Langerhans cells. J Allergy Clin Immunol. 2008;121:368-74. e361.

34. Bagnasco M, Passalacqua G, Villa G, Augeri C, Flamigni G, Borini E, et al. Pharmacokinetics of an allergen and a monomeric allergoid for oromucosal immunotherapy in allergic volunteers. Clin Exp Allergy. 2001;31:54-60.

35. Lima MT, Wilson D, Pitkin L, Roberts A, Nouri-Aria $\mathrm{K}$, Jacobson $\mathrm{M}$, et al. Grass pollen sublingual immunotherapy for seasonal rhinoconjunctivitis: a randomized controlled trial. Clin Exp Allergy. 2002;32(4):507-14.

36. Scadding GW, Shamji MH, Jacobson MR, Lee DI, Wilson D, Lima MT, et al. Sublingual grass pollen immunotherapy is associated with increases in sublingual Foxp3-expressing cells and elevated allergenspecific immunoglobulin G4, immunoglobulin A and serum inhibitory activity for immunoglobulin Efacilitated allergen binding to B cells. Clin Exp Allergy. 2010;40(4):598-606.
37. Passalacqua G, Albano M, Riccio A, Fregonese L, Puccinelli P, Parmiani S, et al. Clinical and immunologic effects of a rush sublingual immunotherapy to Parietaria species: a double-blind, placebo-controlled trial. J Allergy Clin Immunol. 1999;104:964-8.

38. Passalacqua G, Senna G, Dama A, Riccio A, Crivellaro $\mathrm{M}$, Canonica GW. The relationship between clinical efficacy of specific immunotherapy and serum intercellular adhesion molecule-1 levels. J Investig Allergol Clin Immunol. 1998;8:123-4.

39. Ippoliti F, De Santis W, Volterrani A, Lenti L, Canitano N, Lucarelli S, et al. Immunomodulation during sublingual therapy in allergic children. Pediatr Allergy Immunol. 2003;14:216-21.

40. Bahceciler NN, Arikan C, Taylor A, Akdis M, Blaser K, Barlan IB, et al. Impact of sublingual immunotherapy on specific antibody levels in asthmatic children allergic to house dust mites. Int Arch Allergy Immunol. 2005;136:287-94.

41. Bohle B, Kinaciyan T, Gerstmayr M, Radakovics A, Jahn-Schmid B, Ebner C. Sublingual immunotherapy induces IL-10-producing T regulatory cells, allergenspecific T-cell tolerance, and immune deviation. J Allergy Clin Immunol. 2007;120(3):707-13.

42. Fanta C, Bohle B, Hirt W, Siemann U, Horak F, Kraft $\mathrm{D}$, et al. Systemic immunological changes induced by administration of grass pollen allergens via the oral mucosa during sublingual immunotherapy. Int Arch Allergy Immunol. 1999;120:218-24.

43. Rolinck-Werninghaus $\mathrm{C}$, Kopp M, Liebke C, Lange J, Wahn U, Niggemann B. Lack of detectable alterations in immune responses during sublingual immunotherapy in children with seasonal allergic rhinoconjunctivitis to grass pollen. Int Arch Allergy Immunol. 2005;136:134-41.

44. Dehlink E, Eiwegger T, Gerstmayr M, Kampl E, Bohle B, Chen KW, Vrtala S, Urbanek R, Szepfalusi Z. Absence of systemic immunologic changes during dose build-up phase and early maintenance period in effective specific sublingual immunotherapy in children. Clin Exp Allergy. 2006;3632-39.

45. Cosmi L, Santarlasci V, Angeli R, Liotta F, Maggi L, Frosali F, et al. Sublingual immunotherapy with Dermatophagoides monomeric allergoid down-regulates allergen-specific immunoglobulin E and increases both interferon-gamma- and interleukin-10production. Clin Exp Allergy. 2006;36:261-72.

46. Savolainen J, Jacobsen L, Valovirta E. Sublingual immunotherapy in children modulates allergen-induced in vitro expression of cytokine mRNA in PBMC. Allergy. 2006;61:1184-90.

47. Savolainen J, Nieminen K, Laaksonen K, Laiho T, Jacobsen L, Lahesmaa R, et al. Allergen-induced in vitro expression of IL-18, SLAM and GATA-3 mRNA in PBMC during sublingual immunotherapy. Allergy. 2007;62:949-53. 
48. Ciprandi G, Cirillo I, Fenoglio D, Marseglia G, Tosca MA. Sublingual immunotherapy induces spirometric improvement associated with IL-10 production: preliminary reports. Int Immunopharmacol. 2006;6:1370-3.

49. Ciprandi G, Fenoglio D, Cirillo I, Vizzaccaro A, Ferrera A, Tosca MA, et al. Induction of interleukin 10 by sublingual immunotherapy for house dust mites: a preliminary report. Ann Allergy Asthma Immunol. 2005;95:38-44.

50. O'Hehir RE, Gardner LM, de Leon MP, Hales BJ, Biondo M, Douglass JA, et al. House dust mite sublingual immunotherapy: the role for transforming growth factor-beta and functional regulatory T cells. Am J Respir Crit Care Med. 2009;180(10):936-47.

51. Swamy RS, Reshamwala N, Hunter T, Vissamsetti S, Santos CB, Baroody FM, et al. Epigenetic modifications and improved regulatory T-cell function in subjects undergoing dual sublingual immunotherapy. J Allergy Clin Immunol. 2012;130(1):215-7.

52. Soumelis V, Reche PA, Kanzler H, Yuan W, Edward G, Homey B, et al. Human epithelial cells trigger dendritic cell mediated allergic inflammation by producing TSLP. Nat Immunol. 2002;3(7):673-80.

53. Schmitz J, Owyang A, Oldham E, Song Y, Murphy E, McClanahan TK, et al. IL-33, an interleukin-1-like cytokine that signals via the IL-1 receptor-related protein ST2 and induces T helper type 2-associated cytokines. Immunity. 2005;23(5):479-90.

54. Bellinghausen I, Brand U, Steinbrink K, Enk AH, Knop J, Saloga J. Inhibition of human allergic T-cell responses by IL-10-treated dendritic cells: differences from hydrocortisone-treated dendritic cells. J Allergy Clin Immunol. 2001;108(2):242-9.

55. Li X, Yang A, Huang H, Zhang X, Town J, Davis B, et al. Induction of type $2 \mathrm{~T}$ helper cell allergen tolerance by IL-10-differentiated regulatory dendritic cells. Am J Respir Cell Mol Biol. 2010;42(2):190-9.

56. Tversky JR, Bieneman AP, Chichester KL, Hamilton RG, Schroeder JT. Subcutaneous allergen immunotherapy restores human dendritic cell innate immune function. Clin Exp Allergy. 2010;40(1):94-102. PMCID: PMC2837539.

57.• Zimmer A, Bouley J, Le Mignon M, Pliquet E, Horiot $\mathrm{S}$, Turfkruyer $\mathrm{M}$, et al. A regulatory dendritic cell signature correlates with the clinical efficacy of allergen-specific sublingual immunotherapy. J Allergy Clin Immunol. 2012;129(4):1020-30.

First study to propose that stabilin 1 (STAB1) and the complement component $\mathrm{C} 1 \mathrm{Q}$ representing a tolerogenic signature of DCs in SLIT treated patients.

58.• Matsuoka T, Wing Chun F, Stott B, Durham SR, Shamji MH. Immunomodulatory Effects of IL-27 on Allergen-induced Th2 responses. J Allergy Clin Immunol. 2013;131(2):Suppl: AB203.

First study to propose to show IL-27 supresses TH2 allergic responses.
59. Rousseau F, Basset L, Froger J, Dinguirard N, Chevalier S, Gascan H. IL-27 structural analysis demonstrates similarities with ciliary neurotrophic factor (CNTF) and leads to the identification of antagonistic variants. Proc Natl Acad Sci U S A. 2010;107(45):19420-5.

60. Pflanz S, Timans JC, Cheung J, Rosales R, Kanzler H, Gilbert J, et al. IL-27, a heterodimeric cytokine composed of EBI3 and p28 protein, induces proliferation of naive CD4(+) T cells. Immunity. 2002;16(6):779-90.

61. Dahl R, Kapp A, Colombo G, de Monchy JGR, Rak S, Emminger W, et al. Sublingual grass allergen tablet immunotherapy provides sustained clinical benefit with progressive immunologic changes over 2 years. J Allergy Clin Immunol. 2008;121(2):512-8.

62. Frew AJ, Powell RJ, Corrigan CJ, Durham SR, UK Immunotherapy Study Group. Efficacy and safety of specific immunotherapy with SQ allergen extract in treatment-resistant seasonal allergic rhinoconjunctivitis. J Allergy Clin Immunol. 2006;117(2):319-25.

63. Lue KH, Lin YH, Sun HL, Lu KH, Hsieh JC, Chou MC. Clinical and immunologic effects of sublingual immunotherapy in asthmatic children sensitized to mites: a double-blind, randomized, placebo-controlled study. Pediatr Allergy Immunol. 2006;17:408-15.

64. Pajno GB, Barberio G, De Luca F, Morabito L, Parmiani S. Prevention of new sensitizations in asthmatic children monosensitized to house dust mite by specific immunotherapy. A six-year followup study. Clin Exp Allergy. 2001;31(9):1392-7.

65.• Saleem N, Chaker A, Zissler U, Schmidt-Weber CB, Durham SR, Shamji MH. Local nasal "Protective" immunoglobulin G4 (IgG4) responses in nasal fluid following grass pollen sublingual immunotherapy. J Allergy Clin Immunol. Elsevier; 2013;131(2):AB202-2.

First study to demonstrate local Ig4 antibody inhibit IgE-facilitated allergen binding and presentation.

66. Gehlar K, Schlaak M, Becker W-M, Buffe A. Monitoring allergen immunotherapy of pollen-allergic patients: the ration of allergen-specific IgG4 to IgG1 correlates with clinical outcome. Clin Exp Allergy. 1999;29:497-506.

67. Moverare R, Vesterinen E, Metso T, Sorva R, Elfman L, Haahtela T. Pollen-specific rush immunotherapy: clinical efficacy and effects on antibody concentrations. Ann Allergy Asthma Immunol. 2001;86(3):337-42.

68. van Neerven RJ, Wikborg T, Lund G, Jacobsen B, Brinch-Nielsen A, Arnved J, et al. Blocking antibodies induced by specific allergy vaccination prevent the activation of CD4+ T cells by inhibiting serum-IgEfacilitated allergen presentation. J Immunol. 1999;163(5):2944-52. 
69. Wachholz PA, Soni NK, Till SJ, Durham SR. Inhibition of allergen-IgE binding to B cells by IgG antibodies after grass pollen immunotherapy. J Allergy Clin Immunol. 2003;112(5):915-22.

70. Cooke RA, Bernhard JH, Hebald S, Stull A. Serological evidence of immunity with coexisting sensitization in hay fever type of human allergy. J Exp Med. 1935;62:733-51.

71. Lichtenstein LM, Norman PS, Winkenwerder WL. Antibody response following immunotherapy in ragweed hay fever: allpyral vs. whole ragweed extract. J Allergy. 1968;41(1):49-57.

72. Platts-Mills TA, von Maur RK, Ishizaka K, Norman PS, Lichtenstein LM. IgA and IgG anti-ragweed antibodies in nasal secretions. Quantitative measurements of antibodies and correlation with inhibition of histamine release. J Clin Invest. 1976;57(4):1041-50.

73.• James LK, Shamji MH, Walker SM, Wachholz PA, Francis JN, Jacobson MR, et al. Long-term tolerance after allergen immunotherapy is accompanied by selective persistence of blocking antibodies. J Allergy Clin Immunol. 2011;127(2):509-16. e501-505.

First study to demonstrate persistence of blocking antibodies following discontinuation of AIT.

74. Shamji MH, Wilcock LK, Wachholz PA, Dearman RJ, Kimber I, Wurtzen PA, et al. The IgE-facilitated allergen binding (FAB) assay: validation of a novel flow-cytometric based method for the detection of inhibitory antibody responses. J Immunol Methods. 2006;317(1-2):71-9.

75.• Shamji MH, Francis JN, Wurtzen PA, Lund K, Durham SR, Till SJ. Cell-free detection of allergen-IgE crosslinking with immobilized phase CD23: Inhibition by blocking antibody responses after immunotherapy. J Allergy Clin Immunol. 2013;132(4):1003-4.

First study to report a novel solid phase assay for measuring serum inhibitory blocking activity in AIT treated individuals.

76. Wurtzen PA, Lund G, Lund K, Arvidsson M, Rak S, Ipsen H. A double-blind placebo-controlled birch allergy vaccination study II: correlation between inhibition of IgE binding, histamine release and facilitated allergen presentation. Clin Exp Allergy. 2008;38(8):1290-301.

77. Petersen $\mathrm{AB}$, Gudmann P, Milvang-Gronager P, Mørkeberg R, Bøgestrand S, Linneberg A, et al. Performance evaluation of a specific IgE assay developed for the ADVIA centaur immunoassay system. Clin Biochem. 2004;37(10):882-92.

78.• Nelson HS, Nolte H, Creticos P, Maloney J, Wu J, Bernstein DI. Efficacy and safety of timothy grass allergy immunotherapy tablet treatment in North American adults. J Allergy Clin Immunol. 2011;127(1):72-80. 80 e71-72.

First placebo controlled study to show that Patients with timothy grass-and other related grass-induced allergic rhinoconjuctivitis in North America can be treated safely and effectively with timothy grass AIT treatment.

79. Russell MW, Mansa B. Complement-fixing properties of human IgA antibodies. Alternative pathway complement activation by plastic-bound, but not specific antigen-bound, IgA. Scand J Immunol. 1989;30(2):175-83.

80. Pilette C, Nouri-Aria KT, Jacobson MR, Wilcock LK, Detry B, Walker SM, et al. Grass pollen immunotherapy induces an allergen-specific IgA2 antibody response associated with mucosal TGF-beta expression. J Immunol. 2007;1\(7):4658-66.

81. Di Lorenzo G, Mansueto P, Pacor ML, Rizzo M, Castello F, Martinelli N, et al. Evaluation of serum sIgE/total IgE ratio in predicting clinical response to allergen-specific immunotherapy. J Allergy Clin Immunol. 2009;123(5):1103-10.

82. Eifan AO, Akkoc T, Yildiz A, Keles S, Ozdemir C, Bahceciler NN, et al. Clinical efficacy and immunological mechanisms of sublingual and subcutaneous immunotherapy in asthmatic/rhinitis children sensitized to house dust mite: an open randomized controlled trial. Clin Exp Allergy. 2010;40(6):922-32. 